\title{
ARTICLES
}

\section{CONSUMER DISPUTE RESOLUTION GOES ONLINE: REFLECTIONS ON THE EVOLUTION OF EUROPEAN LAW FOR OUT-OF-COURT REDRESS}

\author{
PABlo CoRTÉs and Arno R. LODDER ${ }^{\star}$
}

\begin{abstract}
In this paper we discuss if and to what extent the 2013 EU Regulation on consumer online dispute resolution (ODR) in tandem with the EU Directive on consumer alternative dispute resolution $(A D R)$ is likely to finally fulfil the expectations of ODR that policy makers and academics have had for many years. Part 1 examines the reasons why ODR has not yet taken off. Part 2 discusses previous EU initiatives that aimed to promote the use of ADR and ODR. Part 3 briefly examines the Directive on consumer ADR and the Regulation on consumer ODR, and it compares the EU approach with the UNCITRAL draft rules on ODR. Finally, Part 4 evaluates the obstacles faced in the implementation of the EU ODR Platform, and calls for the embedding of incentives in its operation, the provision of an online negotiation tool, a connection to small claims processes, and the incorporation of adequate tools to overcome language barriers.
\end{abstract}

Keywords: ODR; ADR; consumer law; ombudsman

\section{$\$ 1 . \quad$ INTRODUCTION}

It seems self-evident that parties resolve disputes arising online via the internet, not least because parties in an online transaction may be at a physical distance from each other. A bright future for online dispute resolution (ODR) has been drawn by many scholars since the late 1990s, ${ }^{1}$ but as of yet the use of ODR has been largely disappointing, save

Pablo Cortés is a Senior Lecturer at the School of Law, of University of Leicester. Arno R. Lodder is a Professor of Internet Governance and Regulation, Department of Transnational Legal Studies, VU University Amsterdam.

1 To mention but a few R.C. Bordone, 'Electronic Online Dispute Resolution: A Systems ApproachPotential, Problems and a Proposal', Harvard Negotiation Law Review (1998), p. 175-211; E. Katsh and 
for a limited number of success stories. ${ }^{2}$ This situation contrasts starkly with the growth of E-Commerce. Gradually, more people are using the internet to purchase goods or to receive services, leading to a growing online activity that often has a detrimental impact, and leads to the closure of offline stores. ${ }^{3}$ For those brick-and-mortar stores it is hard to compete with online stores that do not need physical buildings to receive their customers and can be accessed from any place with internet access. ${ }^{4}$ ODR techniques could offer similar advantages to parties in dispute, but alternative dispute resolution (ADR) providers have not moved online, and generally the use of ODR is surprisingly limited.

The lack of mechanisms for redress in E-Commerce has had a knock on effect on the growth of the digital market, particularly amongst SMEs. Indeed, an important constraint on the growth of E-Commerce is the user's lack of trust, who tend to trust recognized online brands more, such as Amazon; or familiar brick-and-mortar stores with well-known brands, such as Apple. Although E-Commerce is regulated by national and regional laws (and note that in fact, online buyers have more legal rights than their offline counterparts), ${ }^{5}$ parties that are in dispute often cannot find a forum to resolve their conflicts in a cost-efficient manner.

The United Nations and the European Union have recently recognized the need to promote the use of ODR methods to enhance options for redress in cross-border trade, particularly in the digital market. Accordingly, the United Nations Commission for International Trade Law (UNCITRAL) established a Working Group (WG III on ODR)

J. Rifkin, Online Dispute Resolution: Resolving Conflicts in Cyberspace (Jossey-Bass, 2001); E. Clark and A. Hoyle, 'Online Dispute Resolution: Present Realities and Future Prospects', 17th Bileta Conference, Amsterdam, 2002, www.bileta.ac.uk/02papers/hoyle.html; C. Rule, Online Dispute Resolution For Business: B2B, E-Commerce, Consumer, Employment, Insurance, and other Commercial Conflicts (Jossey-Bass, 2002); D.A. Larson, 'Online Dispute Resolution: Do You Know Where Your Children Are?', 19 Negotiation Journal 3 (2003), p. 199-205; A.R. Lodder et al. (eds.), Proceedings of the ODRworkshop. org (Edinburgh, 2003); G. Kaufmann-Kohler and T. Schultz, Online Dispute Resolution: Challenges for Contemporary Justice (Kluwer Law International, 2004); J. Hörnle, Cross-Border Internet Dispute Resolution (Cambridge University Press, 2009); P. Cortés, Online Dispute Resolution for Consumers in the European Union (Routledge, 2010); A.R. Lodder and J. Zeleznikow, Enhanced Dispute Resolution Through The Use Of Information Technology (Cambridge University Press, 2010); M. Wahab, E. Katsh and D. Rainey, Online Dispute Resolution: Theory and Practice (Eleven International Publishing, 2012); A.E. Vilalta Nicuesa, Mediación y Arbitraje Electrónicos (Aranzadi, 2013).

2 The best known examples are the online negotiation support of eBay/Square Trade that resolved dozens of millions of disputes, domain name arbitration by WIPO and others settling tens of thousands cases, and the blind bidding site Cybersettle, resolving for a value of over 1 billion dollars. The latter recently stopped their service, see A.R. Lodder, 'Yeah I think Cybersettle is out of the ODR Game', Jurel.nl (2013), http://jurel.nl/2013/05/22/.

3 The Economist, 'The Emporium Strikes Back', 13 July 2013. See also TNS Political \& Social, 'Consumers' attitudes towards cross-border trade and consumer protection', Flash Eurobarometer 332 (2012), p. 14.

4 On the connection between the physical world and the internet, see A.R. Lodder, 'The Ten Commandments of Internet Law revisited: Basic Principles for Internet Lawyers', Information \& Communication Technology Law, forthcoming.

5 See for instance information rights or the cooling off period provided by for distance sales in Directive 2011/83/EU of the European Parliament and of the Council of 25 October 2011 on Consumer Rights, [2011] OJ L 304/64. 
with the aim of providing a legal framework on ODR to facilitate the settlement of lowvalue disputes between businesses, and between consumers and traders. ${ }^{6}$ UNCITRAL's role is to assist in the approximation and compatibility of international trade law in order to stimulate cross-border trade. With this goal in mind, in December 2010, UNCITRAL Working Group III commenced preparation of draft procedural rules that may serve as a model for ODR providers that deal with commercial (B2B) and consumer (B2C and $\mathrm{C} 2 \mathrm{C}$ ) cross-border low-value, high-volume disputes arising from E-Commerce.

In parallel, the EU has also been keen to promote the use of ODR with the aim of stimulating growth in the internal market. By 2000 the E-Commerce Directive had already required national laws to be compatible with the use of ODR techniques. Recital 51 states that: ${ }^{7}$

Each Member State should be required, where necessary, to amend any legislation which is liable to hamper the use of schemes for the out-of-court settlement of disputes through electronic channels; the result of this amendment must be to make the functioning of such schemes genuinely and effectively possible in law and in practice, even across borders.

But the use of ODR did not turn out as hoped for by the EU. A decade later the European Commission considered the development of two legislative instruments with the objective of increasing the ODR options available to European consumers to be justified. This included a Directive on consumer $\mathrm{ADR}^{8}$ and a Regulation on consumer ODR. ${ }^{9}$ Recital 8 of the Regulation on consumer ODR states its main objective as follows:

ODR offers a simple, efficient, fast and low-cost out-of-court solution to disputes arising from online transactions. However, there is currently a lack of mechanisms which allow consumers and traders to resolve such disputes through electronic means; this leads to consumer detriment, acts as a barrier, in particular, to cross-border online transactions, and creates an uneven playing field for traders, and thus hampers the overall development of online commerce.

The EU Regulation requires the creation of an ODR Platform that will become a hub in the EU for all extra-judicial resolution of consumer complaints. The ODR Platform will enable consumers to submit complaints in their own language while nationally approved ADR entities (those complying with the standards set out in the ADR Directive) will be

See www.uncitral.org/uncitral/commission/working_groups/3Online_Dispute_Resolution.html. Directive 2000/31/EC of the European Parliament and of the Council of 8 June 2000 on certain legal aspects of information society services, in particular electronic commerce, in the internal market ('Directive on electronic commerce'), [2000] OJ L 178.

8 Directive 2013/11/EU of the European Parliament and of the Council of 21 May 2013 on alternative dispute resolution for consumer disputes and amending Regulation (EC) No 2006/2004 and Directive 2009/22/EC, [2013] OJ L165/63.

9 Regulation (EU) No 524/2013 of the European Parliament and of the Council of 21 May 2013 on online dispute resolution for consumer disputes and amending Regulation (EC) No 2006/2004 and Directive 2009/22/EC, [2013] OJ L165/1. 
able to deliver their services through the Platform using an online case management tool.

The fact that ODR offers a simple and low-cost resolution is obviously not a new claim, but the EU indicates that the lack of providers of these ODR services is what holds consumers back from using ODR. In this paper we discuss if and to what extent the Regulation on consumer ODR in tandem with the Directive on consumer ADR is likely to finally fulfil the expectations of ODR that have been expressed by both scholars and governments for many years. Part 2 examines the reasons why ODR has not yet taken off. Part 3 discusses prior EU initiatives to promote the use of ADR and ODR. Part 4 analyses the recently approved Directive on consumer ADR and the Regulation on consumer ODR and compares the EU approach to the draft ODR rules that UNCITRAL is developing. Part 5 explains that, as currently envisaged, the Regulation provides for the creation of an ODR clearing house. Accordingly this paper proposes the embedding of incentives for its use, providing a negotiation tool and a connection to small claims processes, and adequate tools to overcome the language barriers.

\section{§2. WHY ODR HAS NOT YET TAKEN OFF}

The first ODR initiatives date back to the 1990s. The best known are The Virtual Magistrate Project, the Online Ombuds Office, and an early experiment resolving eBay disputes that later led to SquareTrade. ${ }^{10}$ Although none of these initiatives survived in their original form, the lessons learned during their development helped to build the following generation of ODR tools, such as the eBay/PayPal Dispute Resolution Centre. ${ }^{11}$

Interest in ODR has also extended to researchers and policy makers. Since 2002, people involved in research, practice, and politics related to ODR all over the world have met regularly at the annual International Forum on ODR. At the second ODR Forum, sponsored in 2003 by the UN in Geneva, one of the main outcomes was the formulation of the following four recommendations:

- That the Member States recognize the need for and value of the use of networked information technology to facilitate conflict resolution.

- That the Member States support experimental projects using technological applications in a range of public and governmental disputes.

- That the issues of digital divide and justice divide be further considered at the annual Forums on Online Dispute Resolution.

- That the UN consults with the Member States about the progress made in the development of instruments of online dispute resolution.

10 E. Katsh, J. Rifkin and A. Gaitenby, 'E-Commerce, E-disputes, and E-dispute Resolution: In the Shadow of "eBay Law", 15 Ohio State J. of Dispute Resolution 3 (2000), p. 705-734.

11 http://resolutioncentre.ebay.co.uk/. 
Since then many successful ODR forums have been organized all over the world (for example, in Cairo, Melbourne, Buenos Aires, Hong Kong, Liverpool, Haifa, Prague, Montreal and Stanford). Needless to say, the expectations that were voiced at the second forum were not fulfilled as quickly as expected. This observation is also reflected in the recent Impact Statement of the ADR Directive and ODR Regulation justifying the need to provide a legal framework in the field of consumer ADR/ODR. ${ }^{12}$ The evaluation of the E-Commerce Directive ${ }^{13}$ shows a similar picture, ${ }^{14}$ the comments on the current condition of ODR being that:

The general consensus in the responses to the consultation was that awareness of ODR mechanisms is either non-existent or poor. Respondents often commented that there is insufficient information provided and publicity given to ODR. ${ }^{15}$

Amongst all the factors that are holding back the development of ODR, perhaps the first and most important one is the lack of awareness, which is indeed mentioned often as a reason for the lack of ODR use, and has in the past also been mentioned in the context of the lack of use of ADR. Consumers with unmet legal needs do not know where to go after an online transaction has gone sour. Businesses know that it is very unlikely that a consumer will commence court proceedings, and they are not aware of what ODR systems may offer them in terms of enhancing consumer redress. Related to the lack of successful ODR is the fact that not many credible trustmarks exist. Trustmarks are online labels that help online users to recognize traders that comply with a code of conduct, and when a consumer believes that there has been a breach of the code, external means of dispute resolution are offered. ${ }^{16}$

A second factor constraining the development of ODR is the lack of legal standards. To date, the ODR field does not have accreditation services, and the same applies to ADR. ${ }^{17}$ Potential users cannot know what to expect from an ODR service provider. The lack of due process guarantees has a knock-on effect on the trust that potential users have in ODR services currently available in the market. Hence, one of the main aims of the ADR Directive, which is explained below, has been to include a list of the minimum

12 Commission staff working paper, Impact Assessment, SEC(2011) 1408 final, http://ec.europa.eu/ consumers/redress_cons/docs/impact_assessment_adr_en.pdf.

13 Directive 2000/31/EC.

14 http://ec.europa.eu/internal_market/E-Commerce/communications/2012/index_en.htm.

15 Summary of the results of the Public Consultation on the future of electronic commerce in the Internal Market and the implementation of the Directive on electronic commerce (2000/31/EC) (2010), http:// ec.europa.eu/internal_market/consultations/docs/2010/E-Commerce/summary_report_en.pdf, p. 15 (under Section '6. Online dispute resolution (Q. 74-77)').

16 See for example the BBB Code of Business Practices (BBB Accreditation Standards), http:/www.bbb. org/us/bbb-accreditation-standards. For a proposal in the EU context see P. Cortes, 'Developing Online Dispute Resolution for Consumers in the EU: A Proposal for the Regulation of Accredited Providers', 19 Int. Jnl. of Law and Info. Technology 1 (2010), p. 1-28. Ibid. 
legal standards with which ODR and ADR providers must comply if they would like to be accredited by the competent authority of a EU Member State.

Another important hurdle is the development of ad hoc ODR technology, which can be very expensive. This third factor is important given the high costs of research on the development of bespoke ODR software. It must be noted that while online ADR may be based on already existing software (such as email, Skype, and so on), generic software will not offer the full potential of ODR in, for example, recognizing patterns of conduct that lead to the settlement of disputes without the intervention of a third neutral party. ${ }^{18}$ Indeed, the development of ODR software that is user-friendly and effective is far from easy. ${ }^{19}$ Against this background, the European Commission has decided to offer the benefits of economies of scale and develop a so-called ODR platform. This will be a web-based ODR platform with an online case management tool, which will be available from the start of 2016 to those ADR entities that have been certified by their national competent authorities as complying with the requirements set in the ADR Directive (and national law that implements it).

Another key requirement for the success of an ODR scheme is for parties to have sufficient incentives to participate in an ODR process outside the courts. Thus, a fourth hurdle is the reluctance of traders to use ODR due to the lack of incentives. Why would a trader who has dismissed a complaint from a consumer choose to participate in an ODR process, especially if the consumer is unlikely to take legal action? The success of the eBay redress system stems from eBay's realization that it was in their own interests that conflicts between their users were resolved efficiently. ${ }^{20}$ For other traders (as opposed to those who operate in a third-party auction site where unhappy buyers leave negative feedback that impact on the subsequent sales of traders) ${ }^{21}$ it will be more difficult to motivate them to participate in ODR schemes. However, the principle remains the same: traders and potential respondents need to be either compelled (by the market or the state) or have economic incentives (for example, reviews, a trustmark, and so forth) to participate in a dispute resolution process.

Finally, the lack of the enforceability of agreements to use ODR, and final outcomes (which has been partly addressed in the EU Mediation Directive discussed below) still poses an important barrier to the use of consensual ODR methods, particularly

18 O. Rabinovich-Einy, 'Technology's Impact: The Quest for a New Paradigm for Accountability in Mediation', 11 Harvard Negotiation Law Review (2006), p. 253.

19 G.A.W. Vreeswijk and A.R. Lodder, 'Gearbi: Towards an online arbitration environment based on the design principles simplicity, awareness, orientation, and timeliness', 13 Artificial Intelligence and Law 2 (2005), p. 297-321.

20 L. Edwards and A. Theunissen, 'Creating Trust and Satisfaction Online: How Important Is ADR? The eBay Experience’, 5 Web Journal of Current Legal Issues (2007).

21 L. Webb, 'International BBB Ratings á la eBay: A Proposal for an Improved Online Better Business Bureau to Facilitate International Business Transactions', 35 California Western International Law Journal (2004), p. 127. 
when using domestic negotiation and mediation (that is, not dealing with cross-border disputes, which fall within the purview of a directive). ${ }^{22}$

Although we do not claim that the above factors form a complete list, we have attempted to sketch the main hurdles that explain the reasons why ODR has not really taken off yet. The EU is very keen to make ODR a successful way of resolving disputes because they have calculated that resolving consumer disputes via ADR/ODR could save billions of euros on a yearly basis, and further stimulate a stagnant internal market. ${ }^{23}$

\section{\$3. THE EU’S ROLE IN FOSTERING THE USE OF ODR}

In 1998 the European Union published a recommendation for 'decision-making bodies'24 and defined seven principles, namely: independence, transparency, adversarial process, effectiveness, legality, liberty and representation. Although the principles can be applied to ODR, the recommendation does not mention the internet or E-Commerce. The year 2000 can be seen as marking the beginning of the EU's formal interest in ODR. ${ }^{25}$ Explicit reference to online mechanisms for dispute resolution can be found in a Council Resolution from June 2000:26

promoting, in this context, the creation of new dispute settlement schemes, in particular with an on-line application.

One month later the often quoted Article 17(1) of Directive 2000/31/EC on E-Commerce was published: ${ }^{27}$

Member States shall ensure that, in the event of disagreement between an information society service provider and the recipient of the service, their legislation does not hamper

22 G. Lázsló Szöke, 'The Possibility of Online Mediation under the Hungarian Mediation Act in Comparison with a Number of International, Including European, Documents on Mediation', 15 Information and Communications Technology Law 2 (2006), p. 129.

23 Commission staff working paper, Impact Assessment, SEC(2011) 1408 final, p. 7: 'Studies have demonstrated that potential savings for European consumers are estimated around $€ 20$ billion if they can refer their dispute to an ADR scheme, while businesses can save up to $€ 3$ billion when using ADR instead of going to court'.

24 Recommendation 98/257/EC on the principles applicable to the bodies responsible for out-of-court settlement of consumer disputes, [1998] OJ L 115, p. 31-34.

25 It should be noted that the efforts to promote the use of ODR for resolving consumer disputes have transcended EU initiatives. An example is the American Bar Association Task Force on E-Commerce and ADR, which recommended Best Practices for ODR Service Providers in 2002.

26 Council Resolution on a Community-wide network of national bodies for the extra-judicial settlement of consumer disputes, [2000] OJ C 155, p. 1-2.

27 Directive 2000/31/EC on certain legal aspects of information society services, in particular electronic commerce, in the internal market, p. 1-16. Also the same hope was expressed in Recital 51 of the E-Commerce Directive: 'the result of this amendment first must be to make the functioning of such schemes genuinely and effectively possible in law and in practice, even across borders'. 
the use of out-of-court schemes, available under national law, for dispute settlement, including appropriate electronic means.

So, while both legal and practical initiatives have envisioned good ODR prospects for the last 10 to 15 years, as noted in the previous section of this paper, ODR did not actually take off as expected.

In 2001, the EU issued a recommendation on mediation ${ }^{28}$ focusing on third parties that do not decide the dispute. In this recommendation four principles (impartiality, transparency, effectiveness, fairness), partly overlapping those included in the previous 1998 Recommendation, were defined. As for the cross-border aspect, recital 6 of the recommendation is illustrative:

Electronic commerce facilitates cross-border transactions (...) New technology can contribute to the development of electronic dispute settlement systems, providing a mechanism to effectively settle disputes across different jurisdictions without the need for face-to-face contact.

Besides the regulatory initiatives, the EU also carried out academic and practical initiatives. The main example of the former is the Electronic Consumer Dispute Resolution (ECODIR project) that ran from 2001 to $2004 .{ }^{29}$ The ECODIR project, headed by Brian Hutchinson, was an academic initiative supported by the European Commission and Irish Department of Enterprise, Trade and Employment. The project was set up in several EU languages to help consumers resolve low-value disputes through a tiered procedure akin to ombudsman processes. It commenced with negotiation, followed by mediation, and offered a recommendation for unresolved disputes. The multi-lingual focus of ECODIR may have complicated an otherwise smooth functioning. Whereas the standard forms could be translated into some EU languages in the fully automated phase, the mediation phase required bilingual mediators that were not always available for each possible combination of EU languages. The limited experience of ECODIR revealed that most cases were resolved in the mediation phase. The project only handled a dozen cases, mainly because of a lack of awareness and the reluctance of respondents to participate, and who often perceived ECODIR as a (biased) consumer protection mechanism that did not take into account traders' rights and interests. ${ }^{30}$ Another significant obstacle to the continuation of ECODIR was the withdrawal of public funding from the European Commission. ${ }^{31}$

28 Recommendation 2001/310/EC on the principles for out-of-court bodies involved in the consensual resolution of consumer disputes, [2001] OJ L 109, p. 56-61.

29 B. Hutchinson, 'ODR and the Future of ADR: Lessons Learnt from ECODIR', Conference on Consumer ADR in Spain and the EU, Madrid, 11-12 December 2006.

30 G. Kaufmann-Kohler and T. Schultz, Online Dispute Resolution: Challenges to Contemporary Justice, p. 339.

$31 \quad$ Ibid., p. 346. 
The EU also launched information portals in various forms and shapes, and the recent ODR Regulation to a certain extent adds to this. In 2001 the EU established a general clearing house for dispute resolution called EEJ-NET, ${ }^{32}$ and another one, FIN-NET, specifically targeted at financial disputes. ${ }^{33}$ These European clearing houses receive complaints from consumers in one Member State against traders or financial service providers from another Member State. The national centres of the clearing houses liaise and contact the parties in their countries with the aim of finding a resolution. When this is not possible, then they put the consumer in touch with the relevant ADR scheme and inform them about their rights. FIN-NET still exists, while EEJ-NET has been continued since 2005 via the European Consumer Centres Network (ECC-Net). ${ }^{34}$ The ECC-Net has at least one office in each Member State and helps consumers primarily when they make online purchases and face cross-border conflicts. The national ECCs inform consumers of their rights and, when they are unable to resolve disputes by negotiating a settlement on behalf of the consumer, then they inform consumers of other available options for redress. Finally, SOLVIT is also worth mentioning as it facilitates the resolution of cross-border disputes that citizens and companies have with public institutions due to the incorrect application of EU law. ${ }^{35}$

This section cannot be concluded without briefly discussing two relevant consumer redress directives: the Mediation Directive ${ }^{36}$ and the Directive on Consumer Rights. ${ }^{37}$ The Mediation Directive aimed at harmonizing many aspects of the mediation process, but during the negotiations many of those included in the 2004 proposal were removed and did not remain in the final text. The goal of this Directive is to encourage the use of mediation for settling cross-border civil and commercial disputes. ${ }^{38}$ The enforceability of agreements resulting from cross-border mediation within the EU is one of the main achievements of the Mediation Directive. ${ }^{39}$ Also worth noting are the inclusion of the confidentiality principle ${ }^{40}$ and the stipulation that parties during the mediation are not to be prejudiced by the expiry of limitation periods of their claims. ${ }^{41}$

32 See Council Resolution on a Community-wide network of national bodies for the extra-judicial settlement of consumer disputes, [2000] OJ C 155, p. 1-2, http://europa.eu/legislation_summaries/ other/132043_en.htm: 'To establish a network of national bodies for the extra-judicial settlement of disputes in order to resolve cross-border consumer disputes quickly and effectively, making use of the new means of communication, particularly the Internet'.

33 http://ec.europa.eu/internal_market/finservices-retail/finnet/index_en.htm.

34 http://ec.europa.eu/consumers/ecc/about_ecc_en.htm.

35 http://ec.europa.eu/solvit/site/index_en.htm.

36 Directive 2008/52/EC of the European Parliament and of the Council of 21 May 2008 on certain aspects of mediation in civil and commercial matters applies mediation of civil and commercial cross-border disputes, [2008] OJ L 136, p. 3-8.

37 Directive 2011/83/EU on consumer rights. Directive 97/7/EC of the European Parliament and of the Council, [2011] OJ L 304, p. 64-88.

Article 1 Directive 2008/52/EC.

39 Article 6 Directive 2008/52/EC. It must also be remembered that the Directive does not apply to Denmark (Article 1).

$40 \quad$ Article 7 Directive 2008/52/EC.

41 Article 8 Directive 2008/52/EC. 
In terms of substantive law it is important to single out the Directive on Consumer Rights, which primarily focuses on information requirements and the right of withdrawal. ${ }^{42}$ It should be noted that in the proposal there was an attempt to deal with the legal fragmentation of consumer protection vis-à-vis ADR that was emerging as a result of minimum harmonization. For instance, the Distance Selling Directive ${ }^{43}$ was seen as a hindrance to 'carry[ing] out alternative dispute resolution mechanisms'. ${ }^{44}$ Also, the Unfair Terms Directive ${ }^{45}$ restricted the use of arbitration by empowering national courts to decide whether a pre-dispute arbitration clause was unfair. This restriction was extended in the first draft of the Consumer Rights Directive, which included in its black list pre-dispute arbitration clauses in consumer contracts, ${ }^{46}$ but this did not make it into the final text of the Directive. Lastly, worth noting is the information that must form an integral part of the distance or off-premises contract: ${ }^{47}$

where applicable, the possibility of having recourse to an out-of-court complaint and redress mechanism, to which the trader is subject, and the methods for having access to it.

Arguably, it would have been better if this information had been obligatory irrespective of whether such a mechanism exists. Indeed, in much sector-specific legislation, the law requires traders to either create internal mechanisms for resolving complaints, or to be linked to external ADR/ODR schemes. ${ }^{48}$

42 The Directive on Consumer Rights (2011/83/EC) will replace, as of 13 June 2014, the current Directive $97 / 7 / \mathrm{EC}$ on the protection of consumers in respect of distance contracts and the current Directive $85 / 577 /$ EEC to protect consumer in respect of contracts negotiated away from business premises.

43 Directive 97/7/EC.

44 Proposal for a Directive on Consumer Rights, COM(2008) 614 final.

45 Directive 93/13/EC.

46 Stating that a contractual clause is considered in all circumstances unfair when 'excluding or hindering the consumer's right to take legal action or exercise any other legal remedy, particularly by requiring the consumer to take disputes exclusively to arbitration not covered by legal provisions', Annex II c), $\operatorname{COM}(2008) 614$ final.

$47 \quad$ Article 5(1)(t).

48 Directive 2008/48/EC of 23 April 2008 on credit agreements for consumers and repealing Council Directive 87/102/EEC, [2008] OJ L 133/66, Article 10(2)(t) and Article 24; Directive 2002/65/EC of 23 September 2002 concerning the distance marketing of consumer financial services and amending Council Directive 90/619/EEC and Directives 97/7/EC and 98/27/EC, [2002] OJ L 271/16, Recital 28, Article 3(4)(a) and Article 14; Directive 2008/122/EC of 14 January 2009 on the protection of consumers in respect of certain aspects of timeshare, long-term holiday product, resale and exchange contracts, [2009] OJ L 33/10, Recital 21 and Article 14; Directive 2008/6/EC of 20 February 2008 amending Directive 97/67/EC with regard to the full accomplishment of the internal market of Community postal services, [2008] OJ L 52/3, Recital 42 and Article 19 as amended in point 18; Directive 2000/31/EC on certain legal aspects of information society services, in particular electronic commerce, in the internal market, Recitals 51 and 52, and Article 1(2) and 17; Directive 2006/123/EC of 12 December 2006 on services in the internal market, [2006] L 376/36, Article 21, 22(3)(e) and 27(4); Regulation (EC) No 1371/2007 of 23 October 2007 on rail passengers' rights and obligations, [2007] OJ L 315/14, Recital 18 and Article 27; Directive 2009/72/EC of 13 July 2009 concerning common rules for the internal market in electricity and repealing Directive 2003/54/EC, [2009] OJ L 211/55, Recital 42, 54, Article 3(7), 3(9) 
The Court of Justice of the European Union (CJEU) held in Alassini that if online redress processes were imposed inappropriately on consumers it would impede their right of access to justice. ${ }^{49}$ In this case the CJEU held that a law establishing pre-action mandatory online conciliation did not breach the right to access to justice provided it did not deny the parties access to the courts after an unsuccessful conciliation and when 'the electronic means is not the only means by which the settlement procedure may be accessed' (for example when the claimant does not have the skills or the resources to use a computer). ${ }^{50}$ Nevertheless, access to technology and skills in its use are rapidly changing, particularly amongst younger generations and E-Commerce participants, so online access seems not to be the only feasible option to resolve the majority of consumer disputes, particularly if they are cross-border or of low-value. ${ }^{51}$

Many elements of what has been discussed in this section are echoed in the recently approved Directive on consumer ADR and the Regulation on consumer ODR. Similarly, the proposed Regulation for a Common European Sales Law (CESL), which allows parties to agree upon this optional body of law to be applicable in lieu of national consumer law, also unifies and clarifies substantive consumer protection rights in contracts for the sale of goods that have been developed in a piecemeal manner. ${ }^{52}$ One could even say that these legislative texts largely mix and merge all existing previous procedural and substantive provisions for consumer sale of goods. One big difference is, however, the legal status of the procedural provisions: whereas some of the above-mentioned principles were only soft instruments - like the 1998 and 2001 Recommendations, the rights and obligations conferred in the ADR Directive have direct legal effect while those contained in the ODR Regulation are directly applicable. We now turn to examine briefly these two initiatives and compare them with UNCITRAL's draft rules for ODR.

(c), 3(12), 3(13) and Annex I 1. (a) and (f); Directive 2003/8/EC to improve access to justice in crossborder disputes by establishing minimum common rules relating to legal aid for such disputes, [2003] OJ L 26/41, Recitals 11 and 21 as well as Article 3(2) and 10; Regulation (EC) No 717/2007 of 27 June 2007 on roaming on public mobile telephone networks within the Community and amending Directive 2002/21/EC, [2007] OJ L 171/32, Article 8(2). See Cases C-317/08-C-320/08 Rosalba Alassini and Others v. Telecom Italia [2010] ECR I-02213. See ibid., para. 67. Compare with J. Davies and E. Szyszczak, 'ADR: Effective Protection of Consumer Rights?', 35 European Law Review 5 (2010), p. 695.

See D. Larson, 'Technology Mediated Dispute Resolution (TMDR): A New Paradigm for ADR', 21 Ohio St. J. on Disp. Resol. (2006), p. 668-670.

European Commission Proposal for a Common European Sales Law, COM(2011) 635 final. See generally S. Whittaker, 'The Proposed 'Common European Sales Law': Legal Framework and Agreement of the Parties', 75 MLR 4 (2012), p. 578-605; S. Whittaker, 'The Optional Instrument on European Contract Law and Freedom of Contract', 7 ERCL (2011), p. 371; and G. Low and J. Smits, 'The Proposed Common European Sales Law: Have The Right Choices Been Made?', 19 MJECL 1 (2012), p. 3-6. 


\section{\$4. THE NEW REGULATORY FRAMEWORK FOR ODR}

\section{A. THE ADR DIRECTIVE AND THE ODR REGULATION}

On 18 June 2013 the Official Journal of the EU published the Directive on Consumer ADR and the Regulation on Consumer ODR. The new laws came into effect 20 days after publication: 8 July. Member States have the obligation to implement the ADR Directive within two years, and the ODR Regulation will become operational six months later. Hence, by July 2015 all Member States must have complied with the requirements of the Directive, the main obligation of which requires Member States to ensure the provision and availability of ADR entities that comply with minimum legal standards when resolving disputes between traders and consumers. The Regulation mandates the European Commission to establish a pan-European ODR Platform that will become a single point of entry for resolving online cross-border consumer complaints arising from E-Commerce. The Platform, which is expected to be fully operational in January 2016, will link complainants to nationally approved ADR entities.

More specifically, the Directive requires Member States to ensure the provision of ADR entities ${ }^{53}$ to resolve national and cross-border contractual complaints between consumers and traders with the exception of disputes related to health services or higher education. ${ }^{54}$ It describes ADR entities as adjudicative and consensual extrajudicial processes created on a durable basis and it excludes complaints handling mechanisms established by the trader, direct negotiation between the consumer and the trader, and judicial settlement. Under the new law traders will be legally obliged to inform consumers about the ADR entities that are competent to deal with potential disputes - this means that traders must inform consumers when they have voluntarily adhered to an ADR/ ODR scheme, and when the law requires them to do so, as is the case in certain sectors where ombudsmen have been created. ${ }^{55}$ Furthermore, all traders, irrespective of whether they are obliged to or intend to use an ADR entity, must also provide information on paper or another durable medium about ADR entities that could handle the consumers' complaints. When doing so, traders must advise whether or not they intend to participate in the ADR process. Although, it appears a bit strange that traders are legally required to inform consumers of ADR entities, even when they have no intention of using them, this obligation was included because it is believed that it will encourage traders to refer disputes to ADR entities by forcing them to consider whether ADR is appropriate in every case. ${ }^{56}$

53 Article 5 Directive 2013/11/EU.

54 Article 2 Directive 2013/11/EU.

55 Article 13 Directive 2013/11/EU.

56 Department for Business Innovation and Skills, 'Implementing the Alternative Dispute Resolution Directive and Online Dispute Resolution Regulation' (March 2014). Available at https://www.gov.uk/ government/consultations/alternative-dispute-resolution-for-consumers. 
Member States will be required to monitor the compliance of these information obligations by traders, but also the functioning of ADR entities, which will be required to notify the public authorities of their rules and performance. In order to ensure compliance, Member States will be able to issue proportionate penalties to traders and ADR entities that do not comply with the information requirements. According to the new Directive, all ADR entities that decide to be accredited and linked to the EU ODR Platform must comply with the following six procedural principles:

I. Expertise, Independence and Impartiality: ${ }^{57}$ third neutral parties must be competent and cannot have conflicts of interest, while collegial bodies must have equal stakeholder representation of consumers and traders;

II. Transparency: ${ }^{58}$ ADR entities must publish annual reports and have a website that displays information to the parties before they agree to participate in the process;

III. Effectiveness: ${ }^{59}$ all ADR entities must offer easy access regardless of their location; they cannot require legal representation; the ADR process must be free of charge or at moderate costs for consumers; and disputes should be resolved within 90 days though in complex disputes ADR entities will be able to extend this period.

IV. Fairness: ${ }^{60}$ Member States must ensure that parties are aware of their rights and the consequences of participating in an ADR procedure. Outcomes must be reasoned and in writing, be provided on paper or in a durable medium (such as email), and before consumers agree to a proposed settlement they must be given the opportunity to reflect before they consent to an amicable solution.

V. Liberty: ${ }^{61}$ contractual agreements to participate in an adjudicative process must be reached with a consumer after the dispute arises if the binding adjudicative process precludes consumers from bringing a legal action before the courts - that is, agreements to go to arbitration must be carried out post-dispute.

VI. Legality: ${ }^{62}$ it states that those processes that impose solutions cannot result in the consumer being offered a lower level of protection than that guaranteed by the mandatory law where the consumer is habitually resident.

The Regulation complements the Directive by establishing an EU-wide ODR Platform that will facilitate the resolution of (both national and cross-border) consumer disputes

Article 6 Directive 2013/11/EU.

Article 7 Directive 2013/11/EU.

Article 8 Directive 2013/11/EU.

Article 9 Directive 2013/11/EU.

Article 10 Directive 2013/11/EU.

Article 11 Directive 2013/11/EU. For cases where there is a conflict of laws the Directive refers to Article 6 of the Rome Regulation (EC) 593/2008, [2008] OJ L 177/6, which states that the applicable law will be where the consumer is habitually resident if the trader has targeted the consumer in his home market (i.e. via advertising, website, etc.). 
related to online sale of goods and provision of services. ${ }^{63}$ European consumers will be able to submit a standard complaint form in their own language, which will be forwarded to the trader in their own language. The interface of the Platform will be a website that will act as a hub to deal with complaints where parties will be invited to agree on using an ADR process to settle their disputes. Although online traders will not be required to participate in any redress mechanism (unless so established by their sectoral laws), they will have the legal obligation to inform consumers about the existence of the ODR Platform, and when they are already subscribed to an ADR scheme. Any nationally approved ADR scheme will need to comply with the six main procedural standards set in the Directive, which under the principle of effectiveness, includes their online access to the whole process. Therefore, in essence all approved ADR entities will employ ODR technology, which could be ad hoc, or using the case management tool provided by the ODR Platform as envisaged in the Regulation. ${ }^{64}$

Consumers (and also traders when the national law thus allows) will be able to submit complaints free of charge and in their own language, but subsequently the ADR providers may charge a reasonable fee and offer its services in a different language to that of the consumer. Each Member State will establish one contact point, which may be part of their national European Consumer Centres, and each contact point will host at least two ODR advisors who will be available to provide parties with technical and language support. ${ }^{65}$

\section{B. THE UNCITRAL DRAFT RULES ON ODR}

Like the EU, the UN has also recognized the need to promote the use of ODR to enhance confidence in cross-border trade. ${ }^{66}$ In 2010 UNCITRAL established a mandate for Working Group III to develop rules for resolving 'cross-border low-value and high-volume' B2B (business to business) and B2C (business to consumer) disputes arising from E-Commerce. ${ }^{67}$ Currently, UNCITRAL rules are being negotiated and only partial consensus has been reached with regard to procedural rules. It must be first noted that the Working Group requested the Secretariat, subject to the availability of resources, to prepare the following documents in addition to the procedural rules: (i) Guidelines for ODR providers and minimum requirements for third neutral parties; (ii) Substantive legal principles for resolving disputes; and (iii) Cross-border enforcement mechanisms.

Article 2 Regulation (EU) No 524/2013.

Article 5(3) Regulation (EU) No 524/2013.

Article 7 Regulation (EU) No 524/2013.

UNCITRAL Working Group III (Online Dispute Resolution). See www.uncitral.org/uncitral/ commission/working_groups/3Online_Dispute_Resolution.html.

67 Official Records of the General Assembly, Sixty-fifth Session, New York, 21 June-9 July 2010, Supplement No. 17 (A/65/17), para. 257. 
UNCITRAL Rules are complementary to the EU initiatives as nationally accredited ADR entities could employ the model procedure that UNCITRAL is now drafting. ${ }^{68}$ Hence, while the EU initiatives provide minimum legal standards for the all types of ADR models and create an ODR platform, UNCITRAL is drafting a model set of procedural rules specifically targeted at promoting the use of ODR for resolving E-Commerce disputes. The UNCITRAL Rules will apply by means of the contractual agreement of the parties, and only to the extent that the Rules are enforceable under the relevant national law. In other words, parties will not be able to rely on the UNCITRAL Rules to overrule national consumer protection laws. ${ }^{69}$ Accordingly, the final legal instrument will be 'model contractual dispute resolution terms', akin to the INCOTERMS developed by the ICC for international trade; thus parties may include them when entering into online transactions. The UNCITRAL Rules establish a fast-track ODR process in stages for resolving low-value disputes. Parties may agree to these Rules either at the time they enter into the transaction or once the dispute arises. The Rules will therefore enable E-Commerce users to agree contractually on the resolution of their disputes to be dealt with according to a tiered process that commences with online negotiation, escalates to facilitated settlement, and culminates in online arbitration (Track I) or non-binding adjudication when parties choose a second track (Track II). Hence, the Rules offer an expeditious procedure where disputes will be adjudicated (within 7 days) when previous attempts to settle have failed. ${ }^{70}$

The goal of both initiatives (the EU's new legislation and the UNCITRAL Rules) is the stimulation of trade, specifically the digital side of cross-border trade. In order to achieve this goal they are issuing regulatory tools which it is hoped will install greater confidence in E-Commerce. These tools in turn aim to promote the use of ODR by intervening in the self-regulatory ODR market by giving market visibility (through an accreditation process) to ODR providers that comply with rules of due process. While both initiatives envisage an accreditation system, the European system takes consumer ODR a step further by requiring Member States to ensure the provision of ADR/ODR entities in compliance with the procedural guarantees established in the ADR Directive. Whereas UNCITRAL proposes a multi-step procedure that moves from automated negotiation up to adjudication, the European consumer ODR initiative extends to various different ADR/ ODR extrajudicial processes. The EU approach intends to reflect the various traditions and models of consumer redress currently found in the EU (for example, ombudsmen,

68 For a critical approach and how the UNCITRAL ODR Rules fit in with the EU approach to consumer protection see P. Cortés and F. Esteban de la Rosa, 'Building A Global Redress System For Low-Value Cross-Border Disputes', 62 ICLQ 2 (2013), p. 407-440 and J. Hörnle, 'Encouraging Online Dispute Resolution in the EU and beyond - Keeping costs low or Standards High?', Queen Mary University of London, Legal Studies Research Paper 122/2012 (2012).

69 UNCITRAL Report of Working Group III (Online Dispute Resolution) on the Work of its TwentyFifth Session, New York, 21-25 May 2012, A/CN.9/774 (7 June 2012), para. 16. See generally V. Nicuesa, Mediación y Arbitraje Electrónicos, p. 169-212.

70 P. Cortés and F. Esteban de la Rosa, 62 ICLQ 2 (2013). 
complaints boards, and so on), ${ }^{71}$ and leaves the establishment of specific procedures to the individual ADR/ODR schemes themselves. This raises the question of whether the approach followed by UNCITRAL is the most suitable one, as one rigid procedural model cannot cover all the diversity and complexity of E-Commerce disputes. ${ }^{72}$

Furthermore, in the European context it has been argued that it would be preferable for legislation to distinguish clearly between binding (or adjudicative) and non-binding (or consensual) processes. ${ }^{73}$ It must also be noted that the CJEU has distinguished predispute mediation clauses from arbitration clauses; the former are only valid provided that they meet the conditions set out by the Court. ${ }^{74}$ The approaches taken by UNCITRAL and the EU on a number of issues, such as the accreditation of ODR providers, cannot yet be fully compared as they are still subject to negotiation and it will be a number of years before these initiatives are finalized and fully implemented. ${ }^{75}$ It is, however, already clear that, once implemented, the models will need to interact with each other, as EU consumers may be offered an ODR process that follows the UNCITRAL Rules. This is because the UNCITRAL process will not only be used to resolve international disputes when the seller is based outside the EU, but it could also be used to settle disputes arising within the internal market.

\section{§5. CHALLENGES TO THE IMPLEMENTATION OF THE EU INITIATIVES}

This paper commenced by noting that there are serious hurdles to the growth of ODR and that the institutional regulatory developments will attempt to overcome some of these obstacles. The ODR Regulation establishes an ODR Platform that aims to increase awareness, and also provides technology to ADR providers with the aim of enabling them to deliver their services online. The ADR Directive sets legal standards to ensure that only quality ADR schemes can use the ODR Platform. Yet, with the exception of those sectors where the law requires traders to participate in an extrajudicial process, it remains unclear whether traders will decide to use ADR methods through the ODR Platform. Although the ODR Regulation obliges online traders to inform consumers about the ODR Platform with a link which must be displayed in their websites, ${ }^{76}$ traders can refuse to participate in the ODR process. Hence, the information obligation could defeat its own purpose, and even be counterproductive, if it misleads consumers

71 C. Hodges, I. Benohr and N. Creutzfeldt-Banda, Consumer ADR in Europe (Civil Justice Systems) (Beck/ Hart, 2012).

72 V. Rogers, Institute of International Commercial Law (Pace Law School), Note on the Resolution Process Designated by the Draft ODR Rules Vienna, 14-18 November 2011.

73 J. Hörnle, Legal Studies Research Paper 122/2012 (2012), section 7.

74 See C-317/08 Rosalba Alassini, para. 67.

75 For instance the EU ODR Platform is scheduled to be fully operational in 2016.

76 Article 14 Regulation (EU) No 524/2013. 
by sending them to an ODR Platform that will not help them to settle their claims. It appears obvious that the information obligation may not be sufficient incentive for traders to participate in an ODR process. ${ }^{77}$ Below we discuss some of key challenges that must be overcome if the ODR Platform is to succeed in fulfilling the potential of ODR: ${ }^{78}$ embedding incentives to encourage its use, broadening the scope of the Platform, establishing effective referral mechanisms, and setting up a mechanism to deal effectively with multilingual disputes.

\section{A. INCENTIVES TO USE ODR}

As has been noted elsewhere, it is the importance of incorporating incentives that encourages traders to participate in the process, ${ }^{79}$ such as legal obligations in those sectors where traders are unreasonably reluctant to engage in ADR (for example, airlines), ${ }^{80}$ connecting the ODR Platform to feedback on review sites, employing a trustmark or online label, and cooperation with search engines so that users can edit their searches in such a way that (reliable) traders committed to ADR will appear first. ${ }^{81}$

In adjudicative processes, regardless of whether binding or non-binding adjudication is employed, the implementation of final outcomes should occur, whenever it is possible, without the need for judicial involvement. Voluntary compliance with awards and final decisions will be more likely when coupled with adequate market incentives such as the publication of awards, especially when one of the parties had not complied with the outcome (black-list). ${ }^{82} \mathrm{~A}$ trustmark logo may also be withdrawn when the vendor does not comply with an award within a certain time period. Furthermore, final outcomes could be communicated to a consumer agency or the relevant public authority in the respondent's home country. In addition, the cooperation with search engines could also facilitate compliance if they give a lower rank to those who refuse to comply with outcomes. Similarly, online payment providers - such as PayPal - can, and often will, include independent ODR mechanisms to deal with complaints. ${ }^{83}$

77 P. Cortés, 'A New Regulatory Framework For Extra-Judicial Consumer Redress: Where We Are And How To Move Forward', University of Leicester Working Paper Series 13-02 (2013). Forthcoming in Legal Studies.

78 For a possible advanced ODR environment see A. Lodder and J. Zeleznikow, 'Developing an Online Dispute Resolution Environment: Dialogue Tools and Negotiation Support Systems in a Three-Step Model', 10 Harvard Negotiation Law Review (2005), p. 287-337.

79 P. Cortés, University of Leicester Working Paper Series 13-02 (2013).

80 ECC-Net Joint Report, 'Alternative Dispute Resolution in the Air Passengers Rights Sector' (February 2013).

81 Ibid.

82 Ibid.

83 See Paypal Resolution Centre at https://www.paypal.com/uk/cgi-bin/webscr?cmd=xpt/cps/general/ PPDisputeResolution-outside. 


\section{B. WHY THE EU ODR PLATFORM AS A CLEARING HOUSE IS NOT GOOD ENOUGH}

The EU's goal is to stimulate the internal market through enhancement of consumer redress mechanisms that would increase trust in a more competitive and integrated cross-border market. In order to improve consumer redress, the EU tries to harness the potential of national ADR schemes to operate efficiently, not only at national, but also at cross-border level. To enable more effective and coordinated redress, the EU has envisaged the construction of an ODR Platform that will operate as a clearing house, linking parties to nationally approved ADR providers.

In line with the concept of a true ODR Platform, it will also offer a case management tool which ADR providers could employ to deliver their services online to the parties involved. However, the particulars of this tool remain to be seen as they are not contained in the ODR Regulation. According to the ODR Regulation, one of the functions of the Platform will be 'offering an electronic case management tool free of charge, which enables the parties and the ADR entity to conduct the dispute resolution procedure online via the ODR platform. ${ }^{84}$ In addition, the preamble of the ODR Regulation states that ADR entities will not be obliged to use the management tool. Although the Regulation does not provide more information on the facilities that this tool will provide, it can be expected that it will support parties to communicate with the nationally approved ADR entities by written messages through the ODR Platform.

In our view, the case management application should be a password-protected section of the ODR Platform and it should offer a number of functions from the Cloud: uploading parties' information (for example, the claim, the response, supporting evidence); enabling communication between the parties and the ADR entities; using an interactive calendar with deadlines; incorporating synchronous and asynchronous communication systems (such as instant messaging and email capabilities); and containing storage and filing systems, allowing the parties to create and manage their case files remotely with appropriate access and read/write privileges. The purpose of this tool should be to provide a variety of case management tools, some of which could be optional or even licensed to ADR entities for a fee, so that they could benefit from sharing developmental costs and economies of scale.

Furthermore, a key element which is currently missing from the ODR Platform is allowing the parties to negotiate within the platform before the dispute is sent to an approved ADR entity. Research has shown that an effective redress mechanism for lowvalue consumer disputes will need to rely on effective automated negotiation tools. ${ }^{85}$ This is because early settlements without the intervention of neutral third parties will be the most (if not the only) cost-efficient way to resolve low-value consumer disputes.

Article 5(3)(b) ODR Regulation.

N. Rogers, R. Bordone, F. Sander and C. McEwen, Designing Systems and Processes for Managing Disputes (Kluwer, 2013), p. 24-25, 250. 
It is expected that a large number of disputes will be related to simple contractual complaints such as an incorrect description and the late/non-arrival of goods. eBay and PayPal (and before SquareTrade) have demonstrated that the immense majority of these disputes can be resolved through 'automated mediation' (aka technology mediated negotiation $)^{86}$ which mimics the functions that a mediator would perform in a face to face environment. ${ }^{87}$ In a nutshell, the buyer-complainant submits a complaint that is forwarded by email to the seller. Because the seller wants to obtain positive feedback for every sale (as this will affect subsequent sales) it is likely that the seller will attempt to settle the complaint. Once the seller fills in the response form, the software examines the possibility of agreement, and if an agreement is not reached, then parties are moved into an electronic interface which sets up a constructive dialogue through reply options, limited free text and short deadlines. The software uses algorithms that compare settlement proposals and suggest agreements by learning from a large database with similar cases. ${ }^{88}$

In most cases parties can reach a settlement, but when this is not possible parties are invited to appoint a neutral third party for a low fee, who will then suggest or impose a settlement. Although this tiered process has been successful in resolving over 60 million disputes a year between eBay users, ${ }^{89}$ the majority of disputes are resolved without human intervention. This is achieved by employing a well-structured online interface that contrasts the submissions made by both parties and emphasizes their shared views as well as the advantages of settlement and consumer satisfaction.

Similarly, the ODR Platform is expected to receive a huge number of consumer disputes. Many of these disputes will be very similar. As eBay has shown, ODR technology can be very helpful in identifying patterns of behaviour and disputes, and building dispute avoidance mechanisms as well as providing parties with the tools to settle these claims without the intervention of humans. These essential cost savings can be ensured by informing parties about their rights and the outcome of similar disputes already adjudicated by neutral third parties.

The European Commission has decided not to develop an online negotiation tool within the ODR Platform. This decision in our view transforms the so-called platform into a clearing house. It is thus up to the accredited ADR entities to offer an online negotiation stage within their own procedures and using their own ODR tools. This stage will be essential when ADR entities deal with low-value complaints, as they need to reduce the costs of involving third neutral parties. However it is argued that since the ODR Platform offers parties a complaint form and a response form, and it will be

86 D. Larson, 21 Ohio State Journal on Dispute Resolution 3 (2006), p. 629.

87 S. Blake, J. Browne and S. Sime, A Practical Approach to Alternative Dispute Resolution (Oxford University Press, 2012), p. 71.

88 O. Rabinovich-Einy, 11 Harvard Negotiation Law Review (2006), p. 253.

89 N. Rogers, R. Bordone, F. Sander and C. McEwen, Designing Systems and Processes for Managing Disputes, p. 24. 
managed by ODR advisors, it will be the obvious place (and the most economical one) to offer the parties an online negotiation tool. This tool, like eBay's tool, should be flexible, improving constantly and adapting to the needs of the online market. Once that is achieved, then we will have a truly ODR Platform.

\section{REFERRALS TO OTHER DISPUTE RESOLUTION METHODS SUCH AS THE SMALL CLAIMS PROCEDURE}

When traders refuse to participate in an ADR process, consumers will be given information through the ODR platform on the suitability of filing a court claim. In the near future, the EU ODR platform might be connected to or complemented by a system of referral to a court procedure, such as collective redress or the European Small Claims Procedure, particularly once e-justice technology is implemented in the national courts. ${ }^{90}$ However, such an option will not be available in the near future at a global level. In some jurisdictions, such as Ireland, consumers may be able to file a claim online. ${ }^{91}$ It is only a question of time before this option is available in national courts across the EU for both domestic and cross-border claims. Indeed, the European Small Claims Procedure (ESCP) Regulation encourages the use of technology to resolve low-value claims within its remit (those below $€ 2,000$ ). ${ }^{92}$ The ESCP is an optional procedure that is offered to claimants alongside the national procedure for dealing with cross-border disputes. As with ADR processes, the ESCP does not require parties to make any legal assessments on the claim, which allows parties to use this dispute resolution process without legal representation.

Furthermore, the ESCP ensures the application of mandatory consumer law as the courts offer rights-based (as opposed to the ADR interest-based approach) dispute resolution. In so doing courts help to correct market abuses. ${ }^{93}$ The European Parliament and the Commission are also looking at ways of developing and encouraging judicial

90 See European Parliament Resolution of 25 October 2011 on Alternative Dispute Resolution in Civil, Commercial and Family Matters (2011/2117(INI)). The e-Justice portal is presently preparing an online filing system for the European Small Claims Procedure, which is expected to start running in 2013. See https://e-justice.europa.eu/home.do?plang=en\&action=home. Compare with P. Cortés, 'Does the Proposed European Procedure Enhance the Resolution of Small Claims?', 27 CJQ 1 (2008), p. 83-97. See Recital 53 of the E-Commerce Directive 2000/31/EC encouraging access to justice by employing appropriate electronic means in the judicial process.

91 P. Cortés, 'Small Claims in Ireland and the EU: The Need for Synergy between National Courts and Extrajudicial Redress', in N. Neuwahl and S. Hammamoun (eds.), The Philosophy of Small Change: Transnational Litigation in the EU and Beyond (Éditions Thémis, 2013), forthcoming.

92 Regulation (EC) 861/2007 establishing a European Small Claims Procedure, [2007] OJ L 199/1. See http://europa.eu/legislation_summaries/consumers/protection_of_consumers/116028_en.htm.

93 H. Eidenmüller and M. Engel, 'Against False Settlement: Designing Efficient Consumer Rights Enforcement Systems in Europe' (July 7, 2013), http://ssrn.com/abstract=2290654 and G. Wagner, 'Private Law Enforcement Through ADR: Wonder Drug Or Snake Oil?', 51 Common Market Law Review, 1 (2014), p. 165-194. 
and extrajudicial collective redress for resolving small claims, ${ }^{94}$ but they seem to want to avoid replicating the US model for class actions. ${ }^{95}$ The Commission has issued a recommendation requiring all the EU Member States to establish collective redress mechanisms. Currently only 16 Member States out of the 28 have such systems. ${ }^{96}$

In contrast to collective redress where parties pool their resources to litigate similar small value disputes, for a small claims procedure to operate efficiently it needs to be affordable and user-friendly, and for online or cross-border disputes it needs to provide parties with distance through the means of communication. Thus, if the ESCP is to operate efficiently, it is paramount for all Member States to initiate a modernization process for their small claims procedures. The European Commission could help in this process by allowing national courts to use an adapted case management tool akin to that which nationally approved ADR entities will use in the ODR Platform.

It must be noted that although the (offline) judicial enforcement of low-value decisions is not currently a feasible option for cross-border disputes (at the European or the international level), the EU has enacted legislation to streamline this process within the internal market. ${ }^{97}$ Conversely, judicial enforcement outside the EU remains more cumbersome, with the possible exception of the enforcement of high value arbitral awards.

Inevitably there will be complaints that either fall outside the scope of the ODR Platform or where ADR schemes are unsuitable - for example vexatious complaints and meritorious complaints where there are indications of fraudulent behaviour. For these types of cases it will be important to identify them early, and when suitable, to redirect them to the ESCP to a collective redress option or to the relevant public enforcement agency.

\section{THE LANGUAGE PROBLEM}

Buying goods in a foreign language is not the same as resolving a dispute in that language. Although this is an issue of serious concern in cross-border disputes, the ADR Directive has not paid much attention to it in its legal provisions, with perhaps the exception of the issues related to communication of information concerning the language of the complaints and the process. ${ }^{98}$ Thus, the complex issue of multi-language disputes remains to be addressed.

94 This is where a third party funding company provides a litigant with funding to bring the litigation in exchange for a percentage of the settlement. See C. Hodges, 'Collective Redress in Europe: The New Model', 29 Civil Justice Quarterly 3 (2010), p. 373 and R. Money-Kyrle and C. Hodges, 'European Collective Action: Towards Coherence?', 19 MJECL 4 (2012), p. 477-504.

95 Commission Recommendation on Common Principles for Injunctive and Compensatory Collective Redress Mechanisms in the Member States Concerning Violations of Rights Granted under Union Law, 11 June 2013, C(2013) 3539/3.

96 For the consultation process in the EU see generally http://ec.europa.eu/consumers/redress_cons/ collective_redress_en.htm.

97 See e.g. Rome I Regulation; Brussels I Regulation, [2001] OJ L 012; and, Mediation Directive, [2008] OJ L $136 / 3$.

98 Article 7(1)(h) Article 19(1)(f), and Article 20(2)(c) Directive 2013/11/EU. 
The ODR Regulation states that the electronic complaints form should be available in all the official languages. ${ }^{99}$ Obviously, this is the right way to start the process, enabling the filing of a complaint in the language the party is familiar with. As long as the form does not have open text fields the information can automatically be translated into any other language, as open text makes the translation much less accurate: this is because while translation software is gradually getting better, it is still far from perfect.

The European Commission is responsible for the operation of the ODR Platform, including all the translation functions necessary for the running of the platform. ${ }^{100}$ But, as mentioned above, the ODR Platform does not offer an online procedure; it only facilitates the filing of the complaint online and redirects parties to nationally approved ADR entities. These entities in turn will be able to choose between using their own technology, or the case management software that will be offered by the ODR Platform.

Most of the information will be contained in the complaints form. This information will often be standardized, and so can be easily offered in all official EU languages. Hence, it seems that only the information in the complaints form will need to be translated under the responsibility of the Commission, since Article 5(4)(e) prescribes that one of the responsibilities of the Platform is:

to provide the parties and ADR entity with the translation of information which is necessary for the resolution of the dispute and is exchanged through the ODR platform.

Thus, it is only the complaint that would be translated before it is communicated by the ODR Platform to the respondent in one of the official EU languages chosen by him. ${ }^{101}$ Moreover, the website hosting the European ODR Platform will be available in all official languages, ${ }^{102}$ but this again is not about the actual ODR process but rather a function of a clearing house, which provides the complaints form and basic case management software. Lastly, the test obligation that the Regulation imposes on the European Commission is noteworthy, ${ }^{103}$ as it requires them to test the technical functionality and user-friendliness of the ODR Platform and the complaints form in all the official languages. Hence, the duties to translate are not that heavy and only specifically refer to the beginning of the process; the complaint form. The actual dispute resolution process will be conducted in the language that the ADR entity chooses; this important limitation can bring insurmountable challenges when resolving multi-lingual disputes.

Having language support for cross-border disputes will be very important if ODR is to be not only an instrument to support the resolution of disputes where parties speak

\footnotetext{
99 Recital 18 Regulation (EU) No 524/2013.

100 Article 5(1) Regulation (EU) No 524/2013.

101 Article 9(3) and Article 9(4) Regulation (EU) No 524/2013. See also Article 9(5)(c) about information of the language the ADR procedure is conducted in, and Annex under 5 and 6.

102 Article 5(2) Regulation (EU) No 524/2013.

103 Article 6(1) Regulation (EU) No 524/2013.
} 
the same language, or when consumers speak the language of the trader, which would only benefit enlightened consumers. Writing skills will also be important as, in order to keep down costs, neutral third parties will often need to make decisions based on written submissions. Furthermore, such a system is likely to favour repeat-players, such as traders.

This approach is not new. Similarly, the ESCP, discussed above, requires the process to be in the language (or in one of the languages) used by the court competent to hear the case. ${ }^{104}$ It also indicates that documents written in a different language will only be translated if it appears to be necessary for the judgment. ${ }^{105}$ The inevitable question then is, how can one establish its relevance if one does not understand the language. This decision will have to be taken by the party who has the onus of proof. It also deals with documents that are in neither the language the court uses, nor a language the addressee understands. ${ }^{106}$ In these circumstances the court may ask for the translation of the document. Such translation requirements slow the process and lead to additional costs. With a direct negotiation this approach often would not work. It presupposes that a party understands two languages, and moreover that a party can translate from one language to the other. It may not come as a surprise that research has shown that the ESCP is more successful in cases with parties in jurisdictions with linguistic similarities than in those where the languages are different. ${ }^{107}$

The Czech Arbitration Court (CAC) (an accredited ODR provider for resolving domain name disputes) has given some consideration to the language of the process, though its rules do not address multi-lingual communication. The CAC simply chooses one language, which will be either the one of the country where the domain name was registered, or when parties so agree, a language that both parties understand. Nevertheless, it is still possible, and even likely, for the process to be conducted in a language in which one of the parties is not proficient, which creates a clear imbalance of power if one of the parties does not have the funds for adequate legal representation. ${ }^{108}$

Lastly, according to UNCITRAL Rules on ODR the language of the proceedings will be chosen by the parties, and if they cannot agree on the language then the neutral third party shall, promptly after its appointment, determine the language or languages to be used in the proceedings. ${ }^{109}$ In practice, when parties disagree on the language of the

104 Article 6(1) Regulation (EU) No 524/2013 states: 'The claim form, the response, any counterclaim, any response to a counterclaim and any description of relevant supporting documents shall be submitted in the language or one of the languages of the court or tribunal.'

Article 6(3) Regulation (EU) No 524/2013. This should be read as an exception to the situation when the courts want to translate the document under Article 6(2).

108 See Alternative Dispute Resolution Rules (the "ADR Rules"), see http://eu.adr.eu.

109 Draft Article 12 UNCITRAL Report of Working Group III (Online Dispute Resolution) on the Work of its Twenty-Seventh Session, New York, 20-24 May 2013, www.uncitral.org/uncitral/commission/ working_groups/3Online_Dispute_Resolution.html. 
process it is expected that the language employed will be the language of the transaction, as it is assumed that that is the mutual language of the parties. ${ }^{110}$ However, the automated part of the ODR process, the negotiation stage, is expected to be multi-lingual, where parties will be offered the use of translation software.

Overall, what is plain is that as long as the multilingual problem is not properly addressed, cross-border disputes between parties from different countries will remain problematic. The ODR Platform will include a translation tool and the national contact points (likely to be housed in the ECCs) will provide language support for consumers. Although only time will tell whether that will be sufficient, there is little doubt that the development of translation tools will improve in a piecemeal manner.

\section{\$6. CONCLUSION}

Despite the fact that ODR processes have not taken off yet, it is clear that existing ADR systems are increasingly incorporating technology in their processes, allowing parties to resolve their disputes, at least partly, online. While it is also obvious that all redress systems have their strengths and weaknesses and no single mechanism is ideal for all types of claims, ODR is clearly suited to resolve consumer disputes, particularly those arising out of E-Commerce. Even for more complex disputes, ODR technology can also offer valuable tools to the neutral third parties.

It is generally accepted that the earlier a dispute is settled, the better it is for everyone involved. Accordingly, there is a need for the ODR Platform to emphasize early resolution, employing an effective negotiation tool and using incentives for parties to participate in ODR processes, to reach early settlements, and to ensure compliance with final outcomes. Technology-assisted negotiation is also essential in the resolution of low value disputes because the cost of involving neutral third parties cannot often be justified. Moreover, even when automated negotiation is not effective in settling a dispute, it can still help in narrowing and clarifying the issues in dispute, which would have an impact in saving costs when reaching a procedural stage where a neutral third party is involved.

It is hoped that the ADR Directive and the ODR Regulation will overcome some of the challenges that have impeded ODR from developing further. Ensuring quality ADR providers cover the EU for all contractual consumer complaints and requiring traders to notify consumers about the ADR schemes and how to get to the ODR Platform should increase awareness of ODR to a significant extent, which in turn will hopefully help to stimulate the internal market. However, for ODR to be effective it will be necessary to ensure that parties, particularly respondents, decide to participate in the ODR process. For that they need incentives. Another big challenge will be to find a cost effective manner of resolving low-value disputes. An obvious way of doing this will be limiting

$110 \quad$ Ibid. 
the need for neutral third parties and using technology as leverage to help parties settle complaints directly. There will also be cases where ADR methods, which are consensus based, will not be suitable. For these cases a connection to small claims processes will be useful and necessary. Lastly, cross-border disputes within the EU bring together parties who speak different languages. The incorporation of adequate tools to overcome the language barriers is an essential element of a puzzle that aims to deliver a cost-efficient redress system. 